\title{
Antihyperurisemic Activity of Aqueous Celery Infusion by Xanthine Oxidase Enzyme Inhibition
}

\author{
Atiqoh Zummah*, Rahma Diyan Martha \\ ${ }^{1}$ Institut Ilmu Kesehatan Bhakti Wiyata, Kediri, Jawa Timur, Indonesia
}

\begin{abstract}
Hyperuricemia is a metabolic disorder because of excessive uric acid production. The high prevalence of hyperuresemia in the world, especially in Indonesia makes the research of antihyperurisemia drugs very needed today. The purpose of this study was to determine the activity of water infusion extract from celery stems and leaves to inhibited xanthine oxidase enzyme. Xanthine oxidase enzyme plays a role in change of hypoxanthine to xanthine and then becomes uric acid. The activity of xanthine oxidase enzyme was determined by UV spectrophotometry method and using xanthine substrate. Absorption at $290 \mathrm{~nm}$ indicates the presence of a uric acid product from xanthine oxidation by the xanthine oxidase enzyme. Infused extract which has the smallest absorption at $290 \mathrm{~nm}$ showed a better inhibitory ability of the xanthine oxidase enzyme because the change of xanthine substrate to uric acid is inhibited. The result showed the celery stems water infusion extract had better inhibition activity than celery leaves water infusion extract. The best inhibition percentage of celery stems water infusion was $90,25 \%$, while the celery leaves water infusion was $69.07 \%$ both of at $20 \%$ concentration. The type inhibition of celery stems water infusion extract to xanthine oxidase enzyme showed an uncompetitive inhibition type because showed change in $K_{m}$ and $V_{\max }$ values. $K_{m}$ and $V_{\max }$ values before the addition of water infusion of celery stems were $104.33 \mathrm{ppm}$ and $3.83 \mathrm{U} / \mathrm{mL}$ respectively changed to $74.49 \mathrm{ppm}$ and $2.69 \mathrm{U} / \mathrm{mL}$ after the addition of extract. Key words: Celery; water infuse; Xanthine oxidase; uric acid; antihyperuresemic
\end{abstract}

\section{INTRODUCTION}

Hyperuricemia is a metabolic disorder due to impaired uric acid excretion (Wyngaarden, 1976). According to Wolf et al., (1999), hyperuricemia could directly induce kidney damage. Hyperuricemia prevalence in Indonesia alone is estimated to have reached $2.3-17.6 \%$ per thousand population (Sudoyo et al., 2006). For patients with hyperuricemia, there will be an increase in serum uric acid levels above normal. It is diagnosed as hyperuricemia if uric acid levels are above $7.0 \mathrm{mg} / \mathrm{dl}$ in adult male and above $6.0 \mathrm{mg} / \mathrm{dl}$ in adult female (Misnadiarly, 2008).

Uric acid is the end product of purine metabolism in humans resulted from the digestion of several foods such as liver, nuts, and others. Normally, uric acid will flow in the blood and carried to the kidneys, which is then excreted in the urine. Due to its low solubility, excessive levels of uric acid can accumulate in various places in the body such as joints and kidneys (Murray, 2003).

One of synthetic drugs used to treat hyperuricemia is allopurinol. The drug can be used to reduce uric acid levels by inhibiting the activity of xanthine oxidase enzyme, an enzyme that plays a role in the formation of uric acid. However, the

*Corresponding author: Atiqoh Zummah Email : atiqohzummah77@gmail.com use of this synthetic drug can cause several side effects such as skin rash, fever, and leucopenia (Dipiro et al., 2008). Thus, it is necessary to encourage research in finding safe therapeutic drugs for hyperuricemia.

Safe alternative treatments for hyperuricemia are possible through the utilization of natural ingredients such as plant extracts. The plants, whose extract is applicable for hyperuricemia treatment, are celeries. Celery plants are known to contain useful chemical compounds, such as flavonoids, alkaloids, glycosides, and steroids in methanol extract of its seeds. It also contains phenols and furocoumarins compounds. The seeds, leaves, and stems of celery are also known to contain essential oils, sesquiterpene alcohols, and fatty acids (A-Snafi, 2014). Some researchers state that celery has many bioactivity properties, including antiinflammatory and pain relievers, antioxidants, antibacterial, antiulcer, antimalarial and larvicidal properties. Anticancer, anti-calculi, antifungal, antihypertensives, fertility enhancer, antithyroid, and antidiabetic (Syahidah, 2018). Plant extracts known to possess activity as hyperuricemia therapy are those containing compounds with the potential to inhibit xanthine oxidase enzymes, namely tannin, flavonoids, polyphenols, and ellagic acid (Azmi etal., 2012). Zhou etal., (2009) 
reported that flavonoid and triterpenoid compounds were successfully isolated from celery leaves. The flavonoid content is expected to be used as xanthine oxidase enzyme inhibitor, making it possible to be used for alternative hyperuricemia treatment. Flavonoids are also known to be easily soluble in water. This study utilized infusion method to obtain extracts from celery because the method is considered to be effective. The method is able to extract compounds and does not use excessive heating or evaporation, so it is possible to make celery extracts in the form of instant herbal drinks in the future. Products in the form of instant herbal drink could be a development giving beneficial health effect to decrease the level of uric acid in the body, as it is expected to possess antihyperuricemia.

\section{METHODOLOGY Test Material}

Celery plants used were obtained from the city of Tulungagung, East Java. Part of celery plant used was the stems and the leaves. Celery plants were washed; stem and leaves were separated. Then, it was sliced into small pieces and aerated in open area. Drying was carried out for 3 days, then powdered and stored in a dark and dry container.

\section{Extraction Material}

The solvent used in the extraction of celery infusion was water. The water used for infusion was mineral-free water.

\section{Activity Test Material}

The enzyme used in testing the activity of celery water infusion extract was the xanthine oxidase enzyme (Sigma Aldrich) and the substrate used was xanthine (Sigma Aldrich). Buffer solution used was $\mathrm{pH} 7.5$ phosphate buffer with a concentration of $50 \mathrm{mM}$. $0.5 \mathrm{M} \mathrm{HCl}$ solution was used for terminating activity test reaction.

\section{Extraction Method}

Dried celery powder from the stem and leaves was weighed 20 grams each. Weighed celery stems and leaves were put into a filter paper bag and tied tightly together. Filter paper bags filled with celery stems and leaves were each dipped in a water solvent that was previously heated at $105^{\circ} \mathrm{C}$. This process was carried out for 1 hour. Extracts from celery stems and leaves water infusion were stored in a dark container.

\section{Activity Test Method}

The inhibitory activity of the xanthine oxidase enzyme was determined by UV spectrophotometry method and by using xanthine substrate. Absorption at $290 \mathrm{~nm}$ indicated the presence uric acid as the product of xanthine substrate oxidation by the xanthine oxidase enzyme. Smaller absorption of uric acid compounds at $290 \mathrm{~nm}$ showed a better inhibitory ability of the xanthine oxidase enzyme because the change from xanthine substrate to uric acid was inhibited. The inhibitory activity test of the xanthine oxidase enzyme was carried out using a modified procedure from Sigma quality control test procedure (1994). $1.5 \mathrm{~mL}$ phosphate buffer solution with a concentration of $50 \mathrm{mM} \mathrm{pH} 7.5$ was mixed with water infusion extracts from $0.4 \mathrm{~mL}$ stems and celery leaves in test tubes so that the solution mixture became $1.9 \mathrm{~mL}$. The solution mixture was added with $1 \mathrm{ml}$ of $0.15 \mathrm{mM}$ xanthine substrate solution. Then, the solution mixture was added with $0.1 \mathrm{ml}$ of xanthine oxidase enzyme solution and was incubated at $25{ }^{\circ} \mathrm{C}$ for 45 minutes. The reaction was stopped by adding $1 \mathrm{ml}$ of $0.5 \mathrm{M}$ $\mathrm{HCl}$. The solution mixture whose reaction had been stopped was measured at wavelength of $290 \mathrm{~nm}$.

The equation used in calculating enzyme activity was:

Enzyme activity (unit $/ m L)=$

Absorbance of testing ${ }_{290}-$ Absorbance of blank ${ }_{290}(3)(d f)$

$$
(12,2)(0,1)
$$

Number 3 in the equation represents the volume of the reaction mixture and the symbol df indicates dilution factor; 12.2 indicates the milimolar extinction coefficient value of uric acid at wavelength of $290 \mathrm{~nm}$, and the number 0.1 indicates the volume of enzyme used (unit/mL).

The inhibition percentage from the extract was carried out with variations in extract concentrations of $20,15.10,5$, and $2.5 \%$. The equation used in the calculation of inhibition percentage was:

$$
\text { Inhibition percentage }=\frac{(A-B)-(C-D)}{(A-B)} \times 100 \%
$$

Symbol A indicates the system absorption without any extract, symbol B indicates system absorption without the addition of enzymes and extracts, symbol $C$ indicates system absorption in the presence of enzymes and extracts, and symbol D indicates system absorption by adding extracts and without enzymes.

\section{Methods of $K_{m}$ and $V_{\text {max }}$ Determination}

The determination of $\mathrm{K}_{\mathrm{m}}$ and $\mathrm{V}_{\max }$ kinetic parameter values was carried out by xanthine substrate variation. Substrate solutions were made with the concentrations of $10,20,40,80,160,320$, 
Table I. The uric acid absorbate of water infusion extract from celery stems and leaves

\begin{tabular}{cc}
\hline Infusa Water Extract (\%) & Absorbance* \\
\hline Control & 0.472 \\
Celery stems 20 & 0.046 \\
Celery stems 15 & 0.237 \\
Celery stems 10 & 0.283 \\
Celery stems 5 & 0.360 \\
Celery stems 2.5 & 0.380 \\
Celery leaves 20 & 0.146 \\
Celery leaves 15 & 0.301 \\
Celery leaves 10 & 0.345 \\
Celery leaves 5 & 0.439 \\
Celery leaves 2.5 & 0.467 \\
\hline
\end{tabular}

* = average of three stipulation

$640,1280,2560$, and $5120 \mathrm{ppm}$. The results of enzyme activity test from each substrate concentration is graphed to contrast the $1 / \mathrm{V}$ with $\mathrm{I} /[\mathrm{S}]$. The $\mathrm{K}_{\mathrm{m}}$ and $\mathrm{V}_{\max }$ values can be determined from the Lineweaver-Burk curve equation produced.

\section{RESULTS AND DISCUSSION}

The extract of celery water infusion tested in this study was from celery's stems and leaves. The testing of extract inhibition activity in this study was observed from the decreasing absorption at wavelength of $290 \mathrm{~nm}$, which indicates the formation of uric acid absorbate. In this study, the substrate was xanthine. The xanthine oxidase enzyme converted hypoxanthine to xanthine, and subsequently became uric acid. The greater the inhibition activity of water infusion extract from celery stems and leaves, the less absorbency of uric acid absorbate will be. The amount of uric acid absorbate from the addition of the stem and leaves water infusion extract (Table I).

Based on (Table I), it can be generally observed that there is uric acid absorbate reduction in the system by adding the water infusion extracts of celery stem and leaves. It indicates that the addition of celery stems and leaves water infusion extracts can inhibit the xanthine oxidase enzyme activity in converting xanthine to uric acid. Deviandra's (2013) study also showed that the uptake of steeped celery was proven to reduce serum uric acid levels in hyperuricemic male white mice.

Based on (Table I) shows that the addition of celery stems infused water extract has lower uric acid uptake compared to the leaves infused water extract. Iswantini (2012) tested the roots of celery and their plants using maceration methods. The results of the Iswantini (2012) study show that the lower part of the plant, the celery root has a better inhibition activity than the plant part. This is indicated by the higher percentage inhibition value of the celery root extract of celery which is equal to $28.27 \%$ at the extract concentration of $200 \mathrm{ppm}$, while the ethanol extract of the celery plant part shows the inhibition percentage of $17.24 \%$ at 200 ppm extract concentration.

The inhibition percentage test results showed that the extract of the celery stem infusion as a whole had a greater percentage of inhibition than celery leaves. The results of the inhibition percentage of water infusion extract from celery stems and leaves (Figure 1).

The results shown in Figure 1 provide information that overall the extract of celery stem infusion has a better inhibitory activity than the extract of celery leaves infusion at the same concentration. Celery stem infusion extract showed the best percentage of inhibition of $90.25 \% \pm 1.27$ at the extract concentration of $20 \%$ and the extract of celery leaf infusion showed the best percentage of inhibition of $69.07 \% \pm 1.39$ at a concentration of $20 \%$. Kolarovic (2010) extracted celery with water solvents using parts of the roots and celery leaves and tested in vivo using rat test animals, the results showed that root water extract showed more ability to increase antioxidative ability by reducing glutathione. Antioxidative ability is thought to be due to the flavonoid content in celery plants. The flavonoid content is also known to be able to inhibit the xanthine oxidase enzyme activity so that it can reduce uric acid levels (Azmi et al., 2012). Based on this, it is indicated that the celery plant part other than leaves is also thought to have biological activity as antihyperuricemia which is no less good than the leaf part.

Figure 1 also shows that the greater the concentration of water infusion extracts from celery stems and leaves inhibition activity is also 


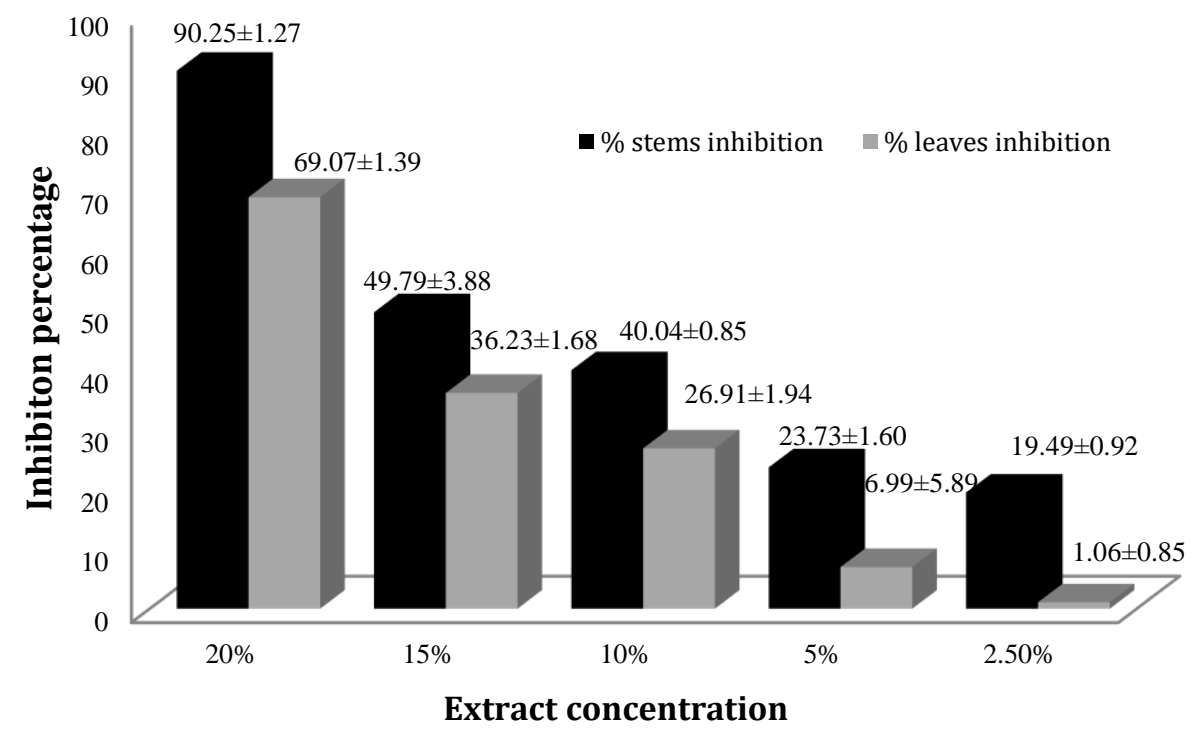

Figure 1. Percentage of inhibition of water infusion extract from celery stems and leaves

Table II. IC 50 value extract of water infusion from celery stems and leaves

\begin{tabular}{|c|c|c|c|c|c|c|c|}
\hline \multirow{2}{*}{ No } & \multirow{2}{*}{$\begin{array}{c}\text { Infused Water } \\
\text { Extract }\end{array}$} & \multicolumn{5}{|c|}{ Inhibis extract percentation (\%) } & \multirow{2}{*}{$\mathrm{IC}_{50}(\%)$} \\
\hline & & $20 \%$ & $15 \%$ & $10 \%$ & $5 \%$ & $2,5 \%$ & \\
\hline 1 & Celery stems & $\begin{array}{c}90.25 \pm \\
1.27^{\mathrm{a}}\end{array}$ & $\begin{array}{c}49.79 \pm \\
3.88^{b}\end{array}$ & $\begin{array}{c}40.04 \pm \\
0.85^{\mathrm{b}}\end{array}$ & $\begin{array}{c}23.73 \pm \\
1.60^{c}\end{array}$ & $\begin{array}{c}19.49 \pm \\
0.92^{\mathrm{d}}\end{array}$ & $\begin{array}{c}11.88 \pm \\
0.20^{\text {aa }}\end{array}$ \\
\hline 2 & Celery leaves & $\begin{array}{c}69.07 \pm \\
1.39 \mathrm{ab} \\
\end{array}$ & $\begin{array}{c}36.23 \pm \\
1.68 \mathrm{bc}\end{array}$ & $\begin{array}{c}26.91 \pm \\
1.94^{\mathrm{cd}} \\
\end{array}$ & $\begin{array}{l}6.99 \pm \\
5.89^{\mathrm{cd}}\end{array}$ & $\begin{array}{l}1.06 \pm \\
0.85^{\mathrm{cd}}\end{array}$ & $\begin{array}{c}16.42 \pm \\
0.31^{\mathrm{bb}}\end{array}$ \\
\hline
\end{tabular}

Description: all values indicate average \pm standard deviation. The same letters behind the mean \pm standard deviation show insignificant differences.

getting better, this is indicated by the greater percentage of inhibition as the concentration of water infusion extract increases. The greater the percentage of inhibition is assumed because at the concentration of water infusion extract, the greater the inhibitor compound in the water infusion extract is bound to the active side of the enzyme so that the formation of uric acid products is inhibited because the amount of substrate enzyme complex decreases.

The results of statistical testing of the inhibition percentage (Table II) also showed that the percentage inhibition of celery stem extract concentrations of $2.5 \%$ to $20 \%$ all differed significantly ( $\mathrm{P}<0.05)$, whereas in leaf extract concentrations of $15 \%$ with $20 \%$ showed a significant difference $(\mathrm{P}<0.05)$, but leaf extract concentrations of $2.5 \%$ to $10 \%$ did not show a significant difference ( $\mathrm{P}>0.05)$. Overall it also showed a significant difference in percent inhibition between stem and leaf extracts (P $<0.05$ ).
The amount of inhibition percentage can also be used to determine the IC 50 of each extract. (Table II) shows the amount of $\mathrm{IC}_{50}$ from each extract of water infusion.

The $\mathrm{IC}_{50}$ value obtained from the extract of celery stem water infusion was significantly smaller $(\mathrm{P}<0.05)$ compared with the $\mathrm{IC}_{50}$ value of the extract of celery leaf infusion. This shows that the extract of celery stem water infusion has a better inhibitory activity of xanthine oxidase enzyme compared to the extract of celery leaves infusion. Furthermore, the inhibition type of the enzyme was determined by the addition of stem extract using several substrate variations. Tests are carried out using the substrate concentration of [S] 10-5120 ppm. The graph of the connection between $1 / \mathrm{V}$ and $1 /[\mathrm{S}]$ produces a LineweaverBurk graph which (Figure 2).

Based on the Lineweaver-Burk enzyme graph without the addition of celery stem extract, the equation $y=27.24 \mathrm{x}+0.261$ obtained from the graph of the connection $1 / \mathrm{V}$ to $1 /[\mathrm{S}]$. The $\mathrm{K}_{\mathrm{m}}$ value 


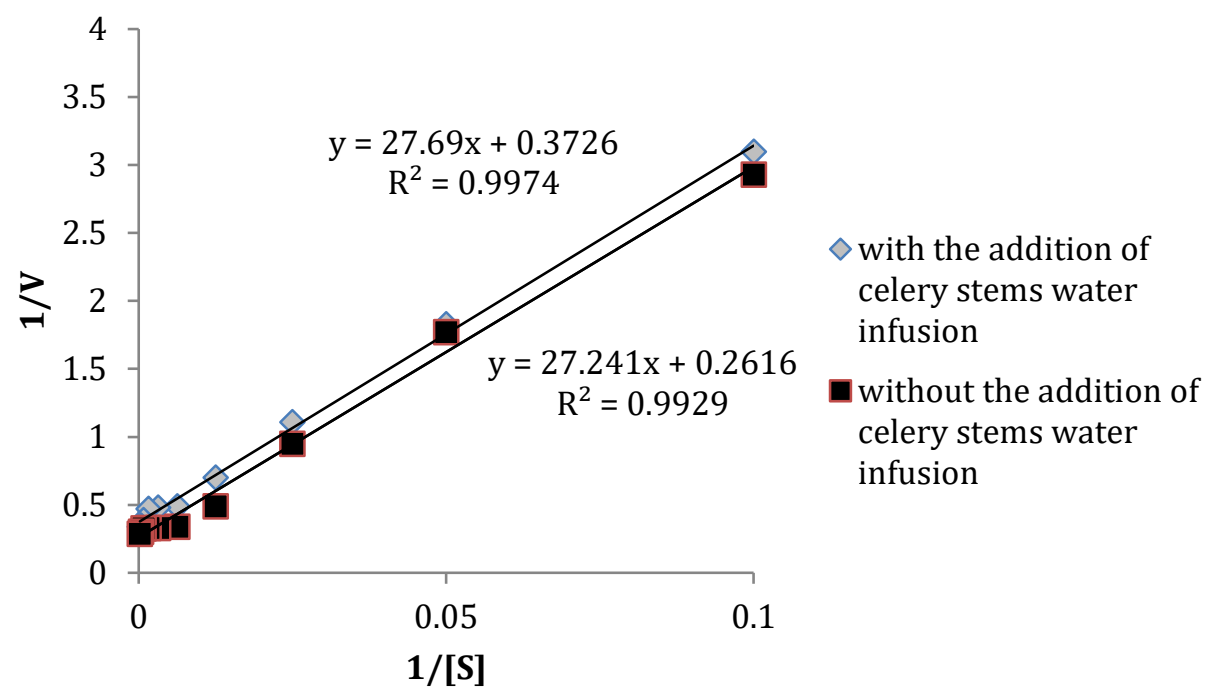

Figure 2. Lineweaver-Burk graph connection 1/V to 1/[S]

of the enzyme without the addition of extract is $104.33 \mathrm{ppm}$ and the $\mathrm{V}_{\text {maks }}$ value is $3.83 \mathrm{U} / \mathrm{mL}$. The enzyme with the addition of celery stem extract obtained the line equation $y=27.69 x+0.372$ from the graph of the connection $1 / \mathrm{V}$ to $1 /[\mathrm{S}]$. The $\mathrm{K}_{\mathrm{m}}$ value produced by the addition of extract is 74.49 ppm and the $V_{\text {maks }}$ value of the equation is 2.69 $\mathrm{U} / \mathrm{mL}$. Changes in $\mathrm{K}_{\mathrm{m}}$ and $\mathrm{V}_{\text {maks }}$ values indicate that the type of inhibitor of celery stem infusion extract is uncompetitive. Uncompetitive inhibitors cannot bind to free enzymes, but bind to the substrate enzyme complex forming an inactive enzymesubstrate-inhibitor complex (Sharma, 2012).

\section{CONCLUSION}

Based on the results it can be concluded that the extract of celery stem water infusion has a better inhibitory activity on the xanthine oxidase enzyme compared to the extract of celery leaf infusion. The best percentage of inhibition from celery stem water infusion extract was $90.25 \% \pm$ 1.27 at an extract concentration of $20 \%$ and the best inhibition percentage of celery leaf infusion extract was $69.07 \% \pm 1.39$ at a concentration of $20 \%$. The inhibition type testing of celery stem extract showed an uncompetitive type of inhibition indicated by changes in $\mathrm{K}_{\mathrm{m}}$ and $\mathrm{V}_{\text {maks }}$ values before and after addition of extracts. The $K_{m}$ value of the enzyme without the addition of extract was 104.33 ppm and the $\mathrm{V}_{\text {maks }}$ value was $3.83 \mathrm{U} / \mathrm{mL}$, while the enzyme with the addition of extract showed $\mathrm{K}_{\mathrm{m}}$ value of $74.49 \mathrm{ppm}$ and $\mathrm{V}_{\text {maks }}$ of $2.69 \mathrm{U} / \mathrm{mL}$.

\section{ACKNOWLEDGEMENTS}

The researcher thanked RISTEKDIKTI for the funds provided through the Penelitian Dosen
Pemula (PDP) and also to Institut Ilmu Kesehatan Bhakti Wiyata for the opportunity given to conduct this research.

\section{REFERENCES}

Al-Snafi., 2014, 'The Pharmacology of apium graveolens-a review, International Journal for Pharmaceutical Research Scholars (IJPRS), 3(1),671-677

Anonim, 1994, 'Enzymatic assay of xanthine oxidase (EC 1.1.3.22)', Sigma quality control test procedure.

Azmi, S., Jamal, P., \&Amid, A., 2012, 'Xantine oxidase inhibitory activity from potential Malaysian medicinal plant as remedie for gout, International Food Research Journal, 19(1), 156-159

Deviandra, R., Safitri, F., \& Handaja, D., 2013, Efek pemberian seduhan seledri (Apium graveolens L.) terhadap kadar asam urat pada tikus putih jantan strain wistar (Rattus norvegicus) hiperurisemia, Jurnal Fakultas Kedokteran Universitas Muhammadiyah Malang, 9(2),75-81

Dipiro, J., Talbert, L., Yee, C., Matzke, R., Wells, G., \& Posey, L., 2008, Paharmacoteraphy, ed 7, McGraw-Hill Companies, Inc., New York.

Iswantini, D., Ramdhani, T.H., \& Darusman, L.K., 2012, 'In vitro inhibition of celery (Apium graveolens L.) extract on the activity of xanthine oxidase and determination of its active compound', Indo. J. Chem., 12(3), 247-254.

Kolarovic, J., Popovic, M., Zlinska, J., Trivic, S., \& Vojnovic, M., 2010, Antioxidant activities of celery and parsley juices in rats treated 
with dexorubicin, Molecules, 15,61936204

Misnadiarly, 2007, Rematik: Asam UratHiperurisemia, Arthritis Gout, ed.1, Pustaka Obor Populer, Jakarta.

Murray, R.K., Granner, D.K., Mayer, P.A., \& Rodwel, V.W., 2003, Biokimia Harper, Translated from Harper's Biochemistry, Penerbit Buku Kedokteran, Jakarta.

Sharma, R., 2012, Enzyme inhibition: mechanisms and scope, Enzyme inhibiton and bioapplications, InTech Web Publishers, Croatia.

Sudoyo, A., Satiyohadi, B., Alwi, I., K, M., \& Setiati, S., 2006, Ilmu Penyakit Dalam, ed 4, Departemen Ilmu Penyakit Dalam
Fakultas Kedokteran Universitas Indonesia, Jakarta.

Syahidah, F.M. \& Sulistiyanigsih, Rr., 2018, Potensi seledri (Apium graveolens) untuk pengobatan: review article, Farmaka, Suplemen 16(1),55-62

Wyngaarden, J.B \& Kelley, W.N., 1976, Gout and Hyperuricemia, Stratton, New York.

Wolf, G., Hegewisch-Becker, S., \& Hossfeld, D.K., 1999, 'Hyperuricemia and renal insufficiency associated with malignant disease: urate oxidase as an efficient therapy', Am. J. Kidney Dis, 34:E20.

Zou, K., Zhao, F., Liu, Z., Zhuang, Y., Chen, L., \& Qiu, F., 2009, 'Triterpenoids and flavonoids from celery (Apium graveolens), J. Nat. Prod., 72(9),1563-7. 